\title{
Phylogeography of an intertidal direct-developing gastropod Batillaria cumingi around the Japanese Islands
}

\author{
Shigeaki Kojima ${ }^{1, *}$, Ikuo Hayashi ${ }^{2}$, Dongsung Kim ${ }^{3}$, Akiko Iijima ${ }^{4}$, Toshio Furota ${ }^{4}$ \\ ${ }^{1}$ Ocean Research Institute, University of Tokyo, 1-15-1 Minamidai, Nakano, Tokyo 164-8639, Japan \\ ${ }^{2}$ Japan Sea National Fisheries Research Institute, Fisheries Research Agency, 1-5939-22 Suido-Cho, Niigata, \\ Niigata 951-8121, Japan \\ ${ }^{3}$ Korea Ocean Research and Development Institute, Ansan PO Box 29, Seoul 425-600, Korea \\ ${ }^{4}$ Faculty of Science, Toho University, 2-2-1 Miyama, Funabashi, Chiba 274-8510, Japan
}

\begin{abstract}
The phylogeography of the direct-developing intertidal gastropod Batillaria cumingi was examined by comparing the nucleotide sequences of part of the mitochondrial gene for cytochrome $c$ oxidase subunit I (COI) from 507 individuals, obtained from 24 sites that cover the distribution area of this species along the Japanese coasts, and from 2 sites on the Korean Peninsula. The individuals could be divided into 2 groups. Individuals in the first group mainly inhabit coasts along the Kuroshio Current, as well as Ariake Bay in western Kyushu, while the second group inhabits coasts along the Tsushima Current and its branches. Individuals in the 2 groups coexisted at only 3 sites, which correspond to the boundaries between the distributions of the 2 groups. The level of the genetic structure of $B$. cumingi is higher than those of the lecithotrophic gastropod species Turbo (Batillus) cornutus and the planktotrophic congeneric species B. multiformis.
\end{abstract}

KEY WORDS: Phylogeography · Direct development - Batillaria cumingi - Mitochondrial DNA · Japanese Islands

Resale or republication not permitted without written consent of the publisher

\section{INTRODUCTION}

The phylogeographic analysis of populations of marine organisms can provide information about historical variations in oceanic environments, since the effects of major environmental changes result in unique and long-retained genetic structures, such as the geographic genetic heterogeneity that is caused by geographic isolation and the extremely low genetic diversity that is caused by population bottleneck effects (Avise 1994, 2000). The concordance of phylogeographic structures among co-distributed species suggests that common historical and/or contemporary oceanographic factors have formed the structures. Such concordances have been reported for marine organisms from the Pacific coast of the United States (Wares et al. 2001), the Atlantic coasts of the NE (Wares 2002) and SE United States (Avise 1992), the
North Atlantic (Wares \& Cunningham 2001), and the Mediterranean Sea (Borsa et al. 1997, Zane et al. 2000).

Two warm water currents, the Kuroshio Current and the Tsushima Current, flow along the Japanese Islands (Fig. 1). The latter branches from the former south of Kyushu, and the currents never meet again. The Tsugaru Current, which is a branch of the Tsushima Current, flows through the Tsugaru Strait and then southward along the coast of the Sanriku district, which is in the NE part of Honshu (the main island of Japan). A cold current, the Oyashio Current, also flows along the coast of the Sanriku district. The Kuroshio Current and the Oyashio Current now meet off the coast of the northern Kanto district, in central Honshu (Fig. 1), but it has been demonstrated that the position of the zone of confluence of these currents fluctuated considerably during the Pleistocene and Holocene eras (Chinzei 1978, Chinzei et al. 1987, Oda \& Takemoto 1992, 


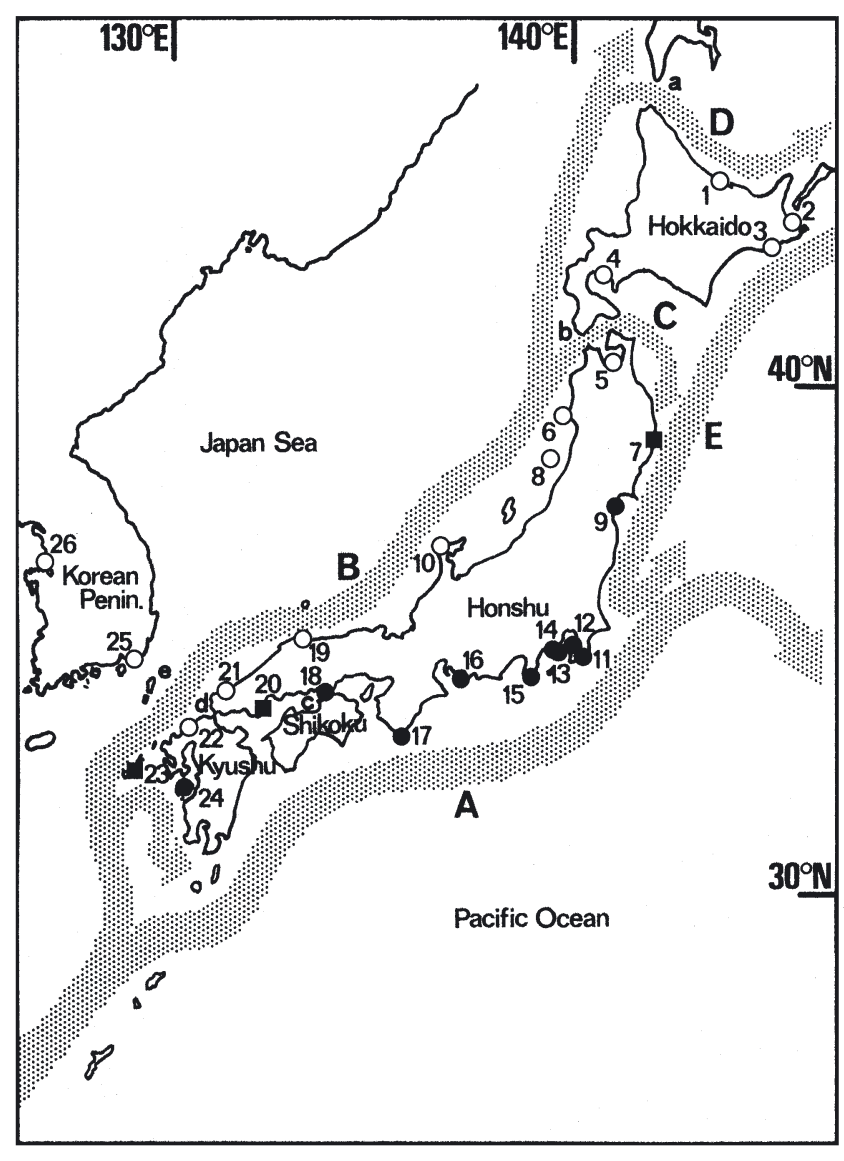

Fig. 1. Sampling sites: 1, Notoroko Lagoon, Hokkaido Prefecture $(\mathrm{N}=20) ; 2$, Furenko Lagoon, Hokkaido Prefecture $(\mathrm{N}=$ $7) ; 3$, Akkeshiko Lagoon, Hokkaido Prefecture $(\mathrm{N}=20) ; 4$, Usu Bay, Hokkaido Prefecture $(\mathrm{N}=20)$; 5, Natsudomari, Aomori Prefecture $(\mathrm{N}=21) ; 6$, Unosaki, Akita Prefecture $(\mathrm{N}=$ 20); 7, Yamada Bay, Iwate Prefecture $(N=20)$; 8 , Tobishima Island, Yamagata Prefecture $(\mathrm{N}=20)$; 9, Torinoumi, Miyagi Prefecture $(\mathrm{N}=20) ; 10$, Minatsuki, Ishikawa Prefecture $(\mathrm{N}=$ 22); 11, Kominato, Chiba Prefecture $(N=20)$; 12, estuary of the Obitsu River, Chiba Prefecture $(\mathrm{N}=20)$; 13, Koajiro Bay, Kanagawa Prefecture $(\mathrm{N}=20)$; 14 , Tenjinjima Island, Kanagawa Prefecture $(\mathrm{N}=20)$; 15 , Nabeta Bay, Shizuoka Prefecture $(\mathrm{N}=20) ; 16$, Shiokawa tidelands, Aichi Prefecture $(\mathrm{N}=$ 20); 17, Kushimoto, Wakayama Prefecture $(\mathrm{N}=16) ; 18$, Bouze Island, Hyogo Prefecture ( $=20) ; 19$, Souzu, Shimane Prefecture $(\mathrm{N}=20) ; 20$, Maehama tidelands, Hiroshima Prefecture $(\mathrm{N}=20) ; 21$, Toragasaki, Yamaguchi Prefecture $(\mathrm{N}=20) ; 22$ ， Hakata Bay, Fukuoka Prefecture $(\mathrm{N}=20)$; 23, Goto Islands, Nagasaki Prefecture $(\mathrm{N}=20)$; 24 , Ariake Bay, Kumamoto Prefecture $(\mathrm{N}=32)$; 25, Ulsuk-do, Gyeongsangnam Prefecture, Korea $(\mathrm{N}=9)$; and 26, Gubongri coast, Gyeonggi Prefecture, Korea $(\mathrm{N}=20)$. Approximate present routes of water currents along the Japanese Islands (according to Unoki and Kubota 1996): (A) the Kuroshio Current, (B) the Tsushima Current, (C) the Tsugaru Current, (D) the Soya Current, and (E) the Oyashio Current are shown. a, b, c, d, and e indicate Soya Strait, Tsugaru Strait, Seto Inland Sea, Kanmon Strait, and Tsushima Strait, respectively. Sites where individuals of $(\bullet)$ the Kuroshio group, (०) the Tsushima group and ( $\bullet$ ) both groups were collected are indicated (see the 'Results' section)
Sawada \& Handa 1998). These complicated current systems around the Japanese Islands are likely to have influenced the distribution and geographic structure of marine organisms, in particular species with low dispersal ability.

Previous studies of a subtidal gastropod with a short planktonic stage, the Japanese turban shell Turbo (Batillus) cornutus, revealed a clear genetic structure that corresponded to the routes of the warm currents along the Japanese coastline (Kojima et al. 1997, 2000). The structure was attributed to environmental changes around Japan during the Quaternary period. The populations of the Japanese turban shell consist of 2 genetically distinct groups, one of which is distributed along the Kuroshio Current and one along the Tsushima Current, while no genetic structure is apparent within each group. If the low dispersal ability of Japanese turban shells is important for the formation and retention of a genetic structure, a clearer structure might be expected for a direct-developing species, and analysis of the genetic structure of such a species might be expected to provide further detailed paleoceanographic information (Kyle \& Boulding 2000, Collin 2001, Hellberg et al. 2001).

Intertidal gastropods of the genus Batillaria are dominant occupants of the muddy tidelands along the Japanese coasts. While 2 planktotrophic species, B. multiformis (Furota et al. 2002) and B. zonalis (S. Kamimura pers. comm.), are now threatened with extinction as a result of the recent exploitation of the Japanese coastline, comparable population declines of the direct-developing B. cumingi (Adachi \& Wada 1999) have not yet been observed (Kurozumi 1995, Wada et al. 1996, Furota et al. 2002). While planktonic larvae may be unable to drift to suitable habitats, which have been isolated from each other by reclamation and severe hypoxia in coastal areas, the direct development of $B$. cumingi is thought to have enabled this species to recruit directly on their parental habitats, resulting in a lower frequency of propagate loss than in species with a long planktonic larval stage (Furota et al. 2002).

Batillaria cumingi has been reported on the coasts of the Japanese Islands, the Korean Peninsula, and continental China (Hasegawa 2000). In spite of its tropical origin, B. cumingi can even be found along the coast of Hokkaido and the northern part of Honshu, where the Japanese turban shell is not present. The 2 warm currents and the Oyashio Current might have played an important role in the dispersal of $B$. cumingi.

In the present study, we analyzed the genetic structure of Batillaria cumingi on the basis of the nucleotide sequences of part of the mitochondrial gene for cytochrome $c$ oxidase subunit I (COI), obtained from specimens collected from 24 sites that cover the distri- 
bution area of this species around the Japanese Islands and from 2 sites on the Korean Peninsula. We discuss the historical factors responsible for the present genetic structure of this species.

\section{MATERIALS AND METHODS}

For the phylogeographic analysis, nucleotide sequences of part of the COI gene obtained from 452 individual specimens of Batillaria cumingi, which had been collected at 22 sites on the Japanese coastline and at 2 sites on the Korean Peninsula (Fig. 1), were determined. Nucleotide sequences of all 52 specimens collected in Ariake Bay and the Goto Islands and for 3 specimens from the Shiokawa tidelands were taken from a previous study (Kojima et al. 2001a).

Total DNA was extracted from the head-foot region of each individual by grinding, digestion with sodium dodecyl sulfate, and extraction with phenol and chloroform. We amplified part (about $700 \mathrm{bp}$ ) of the mitochondrial gene for COI using the polymerase chain reaction (PCR), with total DNA as a template and the primers Gastro-2 (Kojima et al. 2001a) and COI-6 (Shimayama et al. 1990). The conditions for PCR were: $94^{\circ} \mathrm{C}$ for $60 \mathrm{~s}$; then 30 to 40 cycles at $92^{\circ} \mathrm{C}$ for $40 \mathrm{~s}, 50^{\circ} \mathrm{C}$ for $60 \mathrm{~s}$, and $72^{\circ} \mathrm{C}$ for $90 \mathrm{~s}$. Genereleaser ${ }^{\mathrm{TM}}$ (BioVenture) was used to sequester products of cell lysis which might have inhibited the polymerase.

The nucleotide sequence of a $384 \mathrm{bp}$ region of the COI gene, which was previously shown to include sufficient intraspecific variations for phylogeographic analysis (Kojima et al. 2001a), was determined bidirectionally for each specimen with an automated sequencer (DSQ-2000L, Shimadzu) using the internal primers Gastro-4 and UN-1 (Kojima et al. 2001a). The nucleotide sequences of primers used in the present study are summarized in Table 1. Amino acid sequences of COI were deduced by reference to the modified genetic code of molluscan mitochondrial DNA (Shimayama et al. 1990, Hoffmann et al. 1992).

Phylogenetic relationships among haplotypes of Batillaria cumingi were analyzed using the maximumparsimony (MP) method with the program from the
PAUP* package, Version 4.0b10 (Swofford 2002), using the multiple, equally parsimonious, heuristic search option with tree bisection-reconnection and 1000 random addition sequence replicates. $B$. multiformis and B. flectosiphonata, for which the sequences of the COI gene were previously determined by Kojima et al. (2003), were used as an outgroup. The network based on the most parsimonious connections of haplotypes was obtained with the program TCS, Version 1.13 (Clement et al. 2000). The nested clade structure was determined using the rules outlined in Templeton et al. (1987) and Templeton \& Sing (1993). The nested clade analysis was performed using the program GEODIS, Version 2.2 (Posada et al. 2000). The inference key of Templeton et al. (1995) was used to interpret the results.

Differences in haplotype frequencies between populations were examined using the exact test of population differentiation (Raymond \& Rousset 1995) with the computer program package Arlequin (Schneider et al. 2000). An unbiased fixation index, $F_{\mathrm{ST}}$ (Weir \& Cockerham 1984), was estimated and the significance of the indices was tested using a nonparametric permutation approach with Arlequin. The genetic diversity of each population was estimated based on 2 indices: gene diversity, i.e. the probability that 2 randomly chosen haplotypes are different (Nei 1987); and nucleotide diversity, which was expressed by the probability that 2 randomly chosen homologous nucleotides would be different (Tajima 1983, Nei 1987). The neutrality of nucleotide substitutions was tested using the method of Tajima (1989) with Arlequin. The significance of population structure was tested with Analysis of Molecular Variance (AMOVA) using a permutational approach (Excoffier et al. 1992) with Arlequin. Possible population expansion was tested by performing mismatch distribution analysis (Rogers 1995) using Arlequin.

\section{RESULTS}

The 507 individuals of Batillaria cumingi yielded 33 haplotypes. The nucleotide sequences of each hap-

Table 1. Nucleotide sequences of primers used in the present study. $Y, R, S, W$, and $N$ denote $T$ or $C, A$ or $G, G$ or $C, A$ or $T$, and $\mathrm{G}, \mathrm{A} \mathrm{T}$, or $\mathrm{C}$, respectively. Positions refer to the corresponding amino acid residues encoded by the mitochondrial gene for cytochrome $c$ oxidase subunit I (COI) from Drosophila yakuba

\begin{tabular}{|c|c|c|c|}
\hline Name & Sequence & Position & Direction \\
\hline Gastro-2 & 5'-GCGTTCTTTGACCCAGCTGGNGGNGGNGAYCC-3' & $216-226$ & Forward \\
\hline UN-1 & 5'-TTRATTTTACCRGGATTYGG-3' & $244-250$ & Forward \\
\hline Gastro-4 & 5'-ATAATAAARAARTGNTTNGTYCA-3' & $407-415$ & Reverse \\
\hline COI-6 & 5'-GGRTARTCNSWRTANCGNCGNGGYAT-3' & $434-442$ & Reverse \\
\hline
\end{tabular}


Table 2. Batillaria cumingi. Haplotype frequencies of each population. Sampling sites refer to numbers in Fig. 1. Abbreviations of haplotypes are the same as in Fig. 2

\begin{tabular}{|c|c|c|c|c|c|c|c|c|c|c|c|c|c|c|c|c|c|c|c|c|c|c|c|c|c|c|}
\hline \multirow[t]{2}{*}{ Type } & \multicolumn{26}{|c|}{ Sampling site } \\
\hline & 1 & 2 & 3 & 4 & 5 & 6 & 7 & 8 & 9 & 10 & 11 & 12 & 13 & 14 & 15 & 16 & 17 & 18 & 19 & 20 & 21 & 22 & 23 & 24 & 25 & 26 \\
\hline K1 & & & & & & & & & & & & & & & & & & & & & & & & 28 & & \\
\hline K2 & & & & & & & & & & & & & & & & & & & & & & & & 1 & & \\
\hline K3 & & & & & & & & & & & & & & & & & & & & & & & & 1 & & \\
\hline K4 & & & & & & & & & & & & & & & & & & & & & & & & 1 & & \\
\hline K5 & & & & & & & & & & & & & & & & & & & & & & & & 1 & & \\
\hline K6 & & & & & & & & & & & & 6 & 2 & 17 & 20 & 17 & & & & & & & & & & \\
\hline K7 & & & & & & & & & & & & & & & & 1 & & & & & & & & & & \\
\hline K8 & & & & & & & & & & & & 9 & & & & & & & & & & & & & & \\
\hline K9 & & & & & & & & & & & & 3 & & & & & & & & & & & & & & \\
\hline K10 & & & & & & & & & & & & 1 & & & & & & & & & & & & & & \\
\hline K11 & & & & & & & & & & & & & & & & 1 & & & & & & & & & & \\
\hline K12 & & & & & & & & & & & & & & & & 1 & & & & & & & & & & \\
\hline K13 & & & & & & & 1 & & 20 & & 20 & 1 & 18 & 3 & & & 14 & & & & & & & & & \\
\hline K14 & & & & & & & & & & & & & & & & & 1 & & & & & & & & & \\
\hline K15 & & & & & & & & & & & & & & & & & 1 & & & & & & & & & \\
\hline K16 & & & & & & & & & & & & & & & & & & & & & & & 1 & & & \\
\hline K17 & & & & & & & & & & & & & & & & & & 19 & & 8 & & & & & & \\
\hline K18 & & & & & & & & & & & & & & & & & & 1 & & & & & & & & \\
\hline K19 & & & & & & & & & & & & & & & & & & & & 1 & & & & & & \\
\hline T1 & & & & & & 20 & & 20 & & & & & & & & & & & & 11 & & & 4 & & & \\
\hline $\mathrm{T} 2$ & & & & & & & & & & & & & & & & & & & & & & 15 & 10 & & 9 & 14 \\
\hline $\mathrm{T} 3$ & & & & & & & & & & & & & & & & & & & & & & 2 & & & & \\
\hline $\mathrm{T} 4$ & & & & & & & & & & & & & & & & & & & & & & & 1 & & & \\
\hline T5 & & & & & & & & & & & & & & & & & & & & & & 1 & 3 & & & \\
\hline T6 & & & & & & & & & & & & & & & & & & & & & & & & & & 2 \\
\hline $\mathrm{T} 7$ & 20 & 7 & 19 & 20 & 21 & & 16 & & & 22 & & & & & & & & & & & 20 & & & & & 4 \\
\hline T8 & & & & & & & 2 & & & & & & & & & & & & & & & & & & & \\
\hline T9 & & & 1 & & & & & & & & & & & & & & & & & & & & & & & \\
\hline T10 & & & & & & & 1 & & & & & & & & & & & & & & & & & & & \\
\hline T11 & & & & & & & & & & & & & & & & & & & & & & & 1 & & & \\
\hline T12 & & & & & & & & & & & & & & & & & & & 20 & & & & & & & \\
\hline T13 & & & & & & & & & & & & & & & & & & & & & & 1 & & & & \\
\hline T14 & & & & & & & & & & & & & & & & & & & & & & 1 & & & & \\
\hline
\end{tabular}

lotype will appear in the GSDB, DDBJ, EMBL, and NCBI nucleotide sequence databases under accession numbers AB164326 to AB164358. Frequencies of haplotypes within each population are shown in Table 2 . Nucleotide sequences from all haplotypes were of equal length with no insertions or deletions, and could therefore be aligned unambiguously with each other. Nucleotide substitutions occurred at 30 sites within the $384 \mathrm{bp}$ region of the COI gene, and 19 of them were parsimony-informative. The transition/transversion ratio was 8.421. No saturation of nucleotide substitution was revealed (data not shown) and no amino acid substitutions were detected.

Phylogenetic relationships among the haplotypes were analyzed using the MP method. Fig. 2 shows the strict consensus tree of all 5 MP trees. The 33 haplotypes of Batillaria cumingi formed 2 clusters on the MP tree. The monophyly of the first cluster (Haplotypes K1 to 19) was supported by a high bootstrap probability $(90 \%)$, and the value supporting the second cluster (T1 to 14$)$ was relatively low (64\%). A nested haplotype cladogram for B. cumingi with a $95 \%$ plausible set of haplotype connections is shown in Fig. 3. The total cladogram consisted of two 3-step clades, Clades 3-1 and $3-2$, which corresponded to the 2 clusters on the MP tree. The two 3-step clades were separated from each other by 5 nucleotide substitutions. The results of the nested clade analysis are summarized in Table 3.

Haplotypes in Clade 3-1 were distributed along coasts bordering the Kuroshio Current, as well as Ariake Bay (Site 24 in Fig. 1) in western Kyushu, while those in Clade 3-2 were collected mainly from coasts along the Tsushima Current and its branches. Haplotypes of these 2 clades are referred to below as the Kuroshio group and the Tsushima group, respectively. Individuals of the 2 groups were shown to coexist at only 3 sites: in Yamada Bay on the NE coast of Honshu (Site 7 in Fig. 1), on the Maehama tidelands in the Seto Inland Sea (Site 20 in Fig. 1), and on the Goto Islands off NW Kyushu (Site 23 in Fig. 1). These 3 sites corre- 
spond to the boundaries between the distributions of the 2 groups (Fig. 1). The mismatch distribution analysis indicates that both the Kuroshio and Tsushima groups have experienced sudden expansions (Fig. 4), as consistency with the distributions predicted by the sudden expansion model of Rogers (1995) could not be rejected significantly ( $p=0.375$ for the Kuroshio group and $\mathrm{p}=0.119$ for the Tsushima group).

The genetic diversity and nucleotide composition of each population are summarized in Table 4. For the total sample, Tajima's $D$ value was 0.110 and the neutrality of nucleotide substitutions was not rejected $(\mathrm{p}=$ 0.62). Differences in frequencies of haplotypes between populations were examined on the basis of the pairwise $F_{\mathrm{ST}}$ values and using the exact test of population differentiation (Table 5). For AMOVA, sampling sites were divided into 2 groups, i.e. sites where individuals of the Tsushima group predominate and sites where individuals of the Kuroshio group predominate. Significant genetic structures were revealed at 3 levels: among groups, among populations within groups, and within populations, as summarized in Table 6.

\section{DISCUSSION}

\section{Genetic structure of Batillaria cumingi}

The present study revealed a clear genetic structure of the intertidal gastropod Batillaria cumingi around Japan. Adachi \& Wada (1999) reported that B. cumingi, which lacks a planktonic larval stage, can be dispersed as a result of the spread of early juveniles, each of which can float by extending its foot and exploiting the surface tension of water. Dispersal of this species might also be accomplished by rafting on algal beds (Highsmith 1985) or via transportation by birds (Malone 1965). Individuals transported to a new habitat are likely to be easily isolated from their mother population and to accumulate mutations.

The present analysis revealed that populations of Batillaria cumingi consist of 2 genetically distinct groups, the Kuroshio group and the Tsushima group (Figs. $2 \& 3$ ). The former group mainly inhabits coasts along the Kuroshio Current, as well as Ariake Bay (Site 24 in Fig. 1), while the habitats of the latter group are the coasts along the Tsushima Current and its branches (Fig. 1). Using the nucleotide divergence rate of the COI genes of marine gastropods in the genus Tegula, which is $2.4 \%$ per million yr (Hellberg \& Vacquier 1999), we can estimate that a single nucleotide substitution must have been fixed in the sequenced region approximately every $110000 \mathrm{yr}$. It is unlikely that the 2 groups were derived after the beginning of

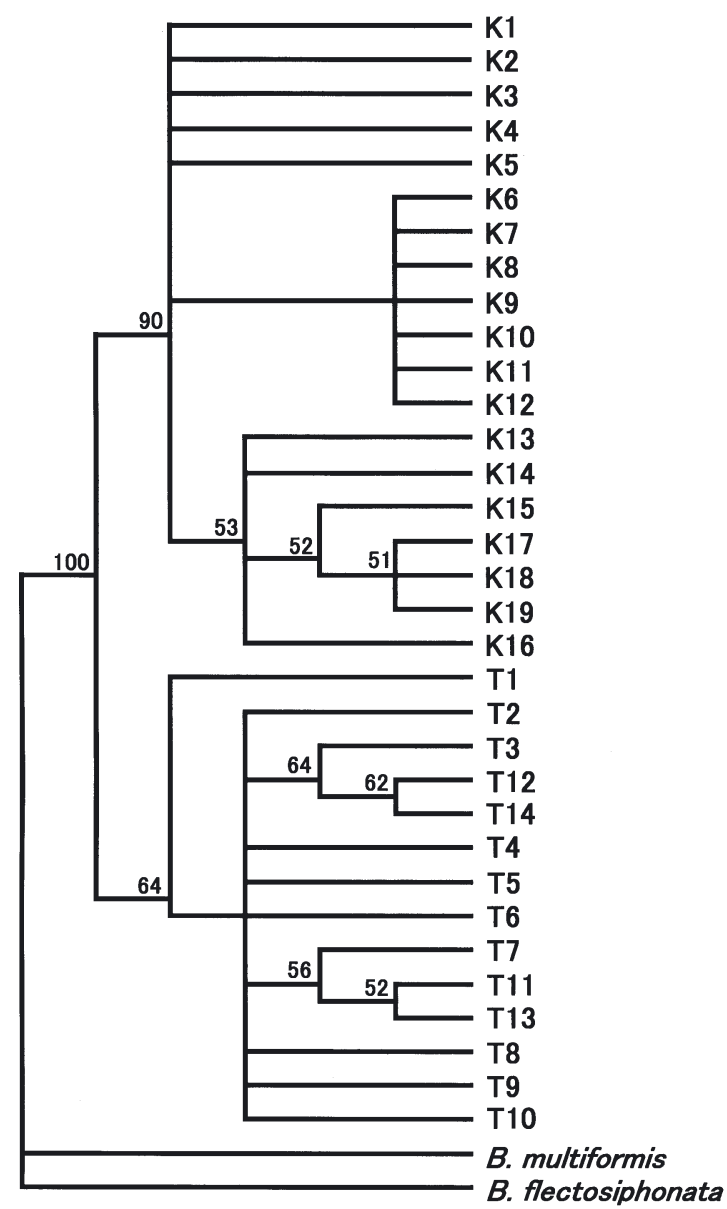

Fig. 2. Batillaria cumingi. Strict consensus tree of all 5 maximum-parsimony (MP) trees (length 89 steps; consistency index excluding non-informative characters, 0.7722 ; retention index, 0.9333 ), which were found in 988 of 1000 replicates. $B$. multiformis and $B$. flectosiphonata were used as an outgroup. A TS/TV ratio of 9:1, which corresponded to the average ratio among sequences of the haplotypes of $B$. cumingi and an outgroup (9.239), was used and the identical tree was obtained at TS/TV ratios of $1: 1,2: 1,4: 1,10: 1,15: 1$, and 20:1. Bootstrap probabilities based on 1000 replicates are shown above branches of clades that are supported by bootstrap values of $>50 \%$

the last glacial period (some $70000 \mathrm{yr}$ ago). The genetic structures of the 2 groups are likely to have been formed as a result of historical changes in the oceanic environment around Japan, as discussed below.

A similar phylogeographic pattern was reported for the Japanese turban shell Turbo (Batillus) cornutus, the larvae of which are lecithotrophic with a short planktonic period of 3 to $5 \mathrm{~d}$ (Kojima et al. 1997, 2000). Individuals of this species inhabiting the Japanese Islands could also be divided into 2 genetically distinct groups, and their distribution corresponds to the routes of the 
Fig. 3. Batillaria cumingi. Nested haplotype cladogram for $B$. cumingi with a $95 \%$ plausible set of haplotype connections. A clade step is shown in the corner of each nesting box. Each line between haplotypes indicates a single nucleotide substitution. Haplotypes not detected in the sample are indicated by open circles. Abbreviations of haplotypes are the same as in Fig. 2

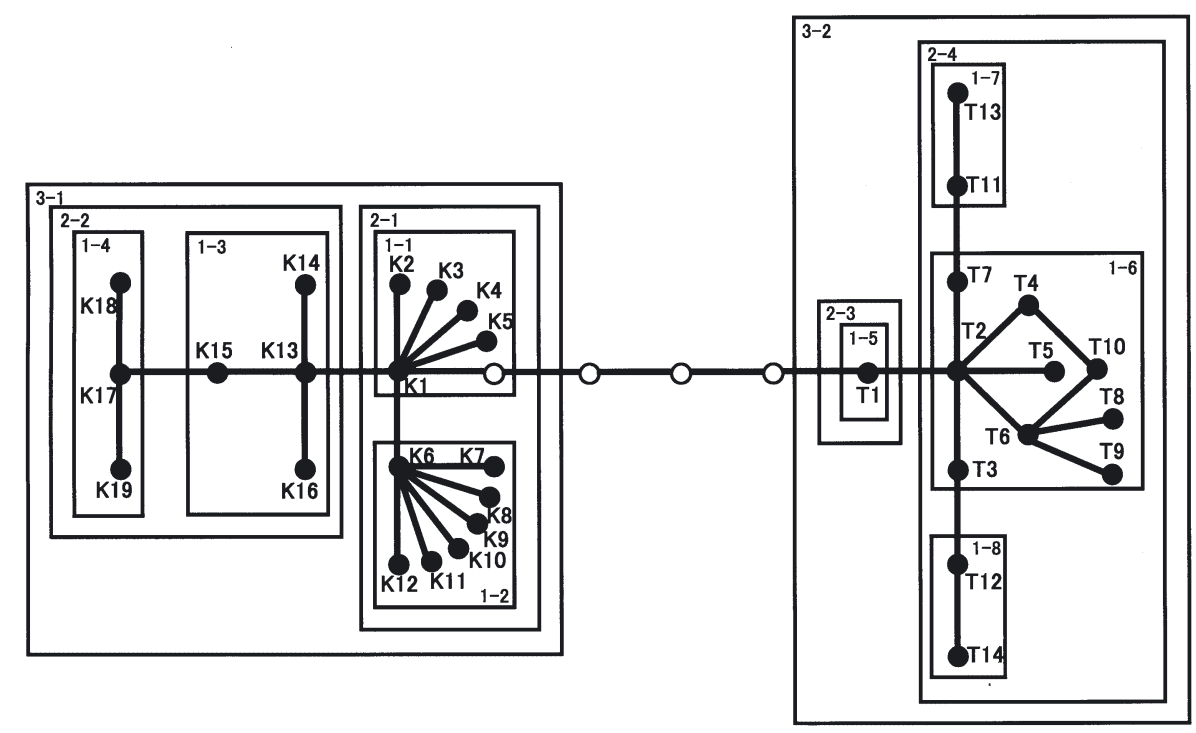

Kuroshio and Tsushima Currents, although the range of this species is narrower than that of Batillaria cumingi, since T. (Batillus) cornutus does not inhabit Hokkaido and the northern part of Honshu. The divergence between the 2 groups of T. (Batillus) cornutus was also estimated to have occurred before the last glacial period (Kojima et al. 2000). No genetic differentiation between local populations was detected for each of the 2 groups of $T$. (Batillus) cornutus, whereas a significant genetic structure was revealed within each of the 2 groups of $B$. cumingi by the test of the significance of $F_{\mathrm{ST}}$ values, the exact test of population differentiation (Table 5), and AMOVA (Table 6). No genetic structure was shown for the planktotrophic species $B$. multiformis, which is congeneric with $B$. cumingi, over its range in the Japanese Islands, despite the existence of 2 genetically distinct groups (Kojima et al. 2003).

Generally speaking, direct-developing species are expected to have lower dispersal abilities than species with a planktonic larval stage, and tend to be more easily geographically isolated, although long-distance dispersal has been reported for some species without any pelagic stage (Martel \& Chia 1991, Helmuth et al. 1994, Johannesson \& Johannesson 1995). Inverse relationships between the level of genetic structures among populations and the expected dispersal capability have been shown for many intertidal molluscs through the comparison of genetic structures of related species with different larval modes (Hoskin 1997, Todd et al. 1998, Kyle \& Boulding 2000, Wilke \& Davis 2000, Collin 2001).

The geographic genetic structures of the 3 Japanese gastropod species mentioned above also correspond with this prediction, i.e. the high level structure of the direct developer Batillaria cumingi, the intermediate level structure of the lecithotrophic species Turbo (Batillus) cornutus, and the lack of geographic structure for the planktotrophic species $B$. multiformis. A single historical event in the Pleistocene might have caused the divergence of 2 lineages in each of these 3 species, and the difference in larval dispersal might have formed their present geographic distribution. A similar phenomenon was reported for gastropods of the genus Crepidula inhabiting the Atlantic and Gulf coasts of North America (Collin 2001). Two species of the C. convexa complex with no or short planktonic periods exclusively inhabit the Atlantic coast or the Gulf coast, while the 2 lineages of the planktotrophic species $C$. fornicate showed no differences in geographic distribution. The fine geographic population structure of $B$. cumingi suggests that dispersal over long distances of this direct-developing species might be a rather rare

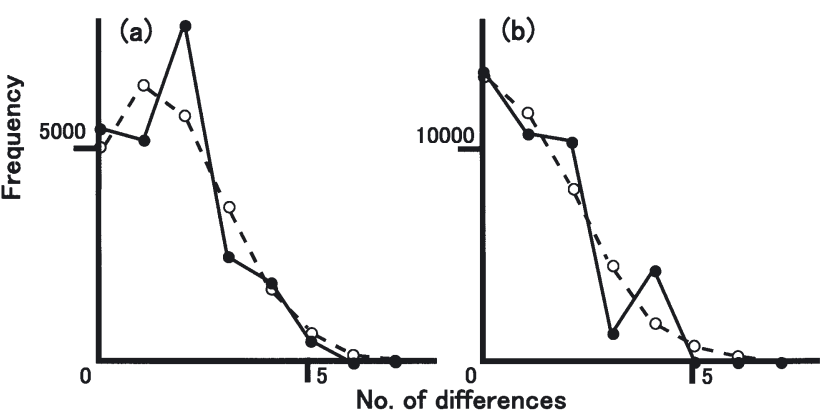

Fig. 4. Batillaria cumingi. Observed and expected distribution of pairwise sequence divergences under the sudden expansion model (Rogers 1995) in individuals of (a) the Kuroshio group and (b) the Tsushima group. (Solid line) observed and (dotted line) expected distributions 
Table 3. Batillaria cumingi. Results of the nested clade analysis of geographic distance for haplotypes. Only clades with significant geographic structure at the 5\% level are included. Dc and Dn denote the clade and nested clade distances, respectively. (I-T)C and (I-T)n are the average difference in distances between interior and tip clades within the nested group for clade and

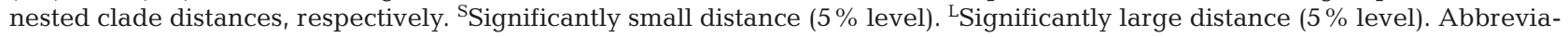
tions of haplotypes are the same as in Fig. 2

\begin{tabular}{|c|c|c|c|c|c|c|c|c|c|}
\hline Nesting & $\mathrm{p}$ & Clade & Location & $\mathrm{Dc}$ & Dn & $(\mathrm{I}-\mathrm{T}) \mathrm{C}$ & $(\mathrm{I}-\mathrm{T}) \mathrm{n}$ & Chain of inference & Inference \\
\hline \multicolumn{10}{|l|}{ 1-Step } \\
\hline \multirow[t]{7}{*}{$1-2$} & 0.022 & K6 & I & 82.8 & $81.4^{\mathrm{S}}$ & & & & \\
\hline & & K7 & $\mathrm{T}$ & 0 & 151.4 & & & & \\
\hline & & K8 & $\mathrm{T}$ & $0^{\mathrm{S}}$ & 94.3 & & & & \\
\hline & & K9 & $\mathrm{T}$ & $0^{\mathrm{S}}$ & 94.3 & \multirow[t]{4}{*}{$82.8^{\mathrm{L}}$} & \multirow{4}{*}{$-23.6^{\mathrm{S}}$} & \multirow[t]{4}{*}{$1-2-3-5-6-7-8-\mathrm{No}$} & Isolation by distance or \\
\hline & & K10 & $\mathrm{T}$ & 0 & 94.3 & & & & long distance dispersal \\
\hline & & K11 & $\mathrm{T}$ & 0 & 151.4 & & & & \\
\hline & & K12 & $\mathrm{T}$ & 0 & 151.4 & & & & \\
\hline \multirow[t]{4}{*}{$1-3$} & 0.013 & K13 & I & $208.8^{\mathrm{S}}$ & $215.2^{\mathrm{S}}$ & \multirow{4}{*}{$206.1^{\mathrm{S}}$} & \multirow{4}{*}{$-455.8^{\mathrm{S}}$} & \multirow{4}{*}{ 1-2-3-5-6-7-Yes } & \\
\hline & & K14 & $\mathrm{T}$ & 0 & 377.6 & & & & Restricted gene flow/ \\
\hline & & K15 & I & 0 & 377.6 & & & & dispersal but with some \\
\hline & & K16 & $\mathrm{T}$ & 0 & $968.7^{\mathrm{L}}$ & & & & long-distance dispersal \\
\hline \multirow[t]{9}{*}{$1-6$} & 0.000 & $\mathrm{~T} 2$ & I & $180.5^{\mathrm{S}}$ & $868.9^{\mathrm{L}}$ & \multirow{9}{*}{376.8} & \multirow{9}{*}{-30.5} & \multirow{9}{*}{ 1-2-3-5-6-13-14-No } & \multirow{9}{*}{$\begin{array}{l}\text { Contiguous range } \\
\text { expansion or long- } \\
\text { distance colonization }\end{array}$} \\
\hline & & T3 & I & 0 & 823.4 & & & & \\
\hline & & $\mathrm{T} 4$ & I & 0 & 977.6 & & & & \\
\hline & & T5 & I & $59.4^{\mathrm{S}}$ & $939.1^{\mathrm{L}}$ & & & & \\
\hline & & $\mathrm{T} 6$ & $\mathrm{~T}$ & 0 & $925.4^{\mathrm{L}}$ & & & & \\
\hline & & $\mathrm{T} 7$ & I & $458.7^{\mathrm{S}}$ & $599.8^{\mathrm{S}}$ & & & & \\
\hline & & T8 & $\mathrm{T}$ & 0 & 431.1 & & & & \\
\hline & & T9 & $\mathrm{T}$ & 0 & 802.6 & & & & \\
\hline & & $\mathrm{T} 10$ & $\mathrm{~T}$ & 0 & 431.1 & & & & \\
\hline \multicolumn{10}{|l|}{ 2-Step } \\
\hline \multirow[t]{2}{*}{$2-1$} & 0.000 & $1-1$ & I & $0^{\mathrm{S}}$ & $671.9^{\mathrm{L}}$ & \multirow[t]{2}{*}{-86.3} & \multirow[t]{2}{*}{$499.2^{\mathrm{L}}$} & \multirow[t]{2}{*}{$1-2-3-5-15-\mathrm{No}$} & \multirow[t]{2}{*}{ Past fragmentation } \\
\hline & & $1-2$ & $\mathrm{~T}$ & $86.3^{\mathrm{S}}$ & $172.7^{\mathrm{S}}$ & & & & \\
\hline \multirow[t]{2}{*}{$2-2$} & 0.000 & $1-3$ & I & $229.0^{\mathrm{S}}$ & $282.7^{\mathrm{S}}$ & \multirow[t]{2}{*}{$139.8^{\mathrm{L}}$} & \multirow[t]{2}{*}{$-82.4^{\mathrm{S}}$} & \multirow[t]{2}{*}{ 1-2-3-5-15-16-18-No } & \multirow{2}{*}{$\begin{array}{l}\text { Fragmentation, range } \\
\text { expansion or isolation } \\
\text { by distance }\end{array}$} \\
\hline & & $1-4$ & $\mathrm{~T}$ & $89.3^{\mathrm{S}}$ & $365.1^{\mathrm{L}}$ & & & & \\
\hline \multirow[t]{3}{*}{$2-4$} & 0.000 & $1-6$ & I & $679.5^{\mathrm{L}}$ & $682.4^{\mathrm{L}}$ & & & & \\
\hline & & $1-7$ & $\mathrm{~T}$ & $44.1^{\mathrm{S}}$ & $469.4^{\mathrm{S}}$ & $689.2^{\mathrm{L}}$ & $186.5^{\mathrm{L}}$ & $1-2-3-4-9-\mathrm{No}$ & Past fragmentation \\
\hline & & $1-8$ & $\mathrm{~T}$ & 0 & 774.8 & & & & \\
\hline 3-Step & & & & & & & & & \\
\hline $3-1$ & 0.000 & $2-1$ & I & 274.6 & $261.1^{\mathrm{S}}$ & -29.3 & $-45.4^{\mathrm{S}}$ & 1-2-11-17-No & Inconclusive outcome \\
\hline & & $2-2$ & $\mathrm{~T}$ & 303.8 & $306.5^{\mathrm{L}}$ & & & & \\
\hline $3-2$ & 0.000 & $2-3$ & I & $381.6^{\mathrm{S}}$ & $393.5^{\mathrm{S}}$ & $-283.9^{\mathrm{S}}$ & $-271.8^{\mathrm{S}}$ & $1-2-11-12-\mathrm{No}$ & Contiguous range \\
\hline & & $2-4$ & $\mathrm{~T}$ & $665.5^{\mathrm{L}}$ & $665.3^{\mathrm{L}}$ & & & & expansion \\
\hline Total & 0.000 & $3-1$ & $\mathrm{~T}$ & $285.4^{\mathrm{S}}$ & $386.0^{\mathrm{S}}$ & & & & \\
\hline cladogram & & $3-2$ & $\mathrm{~T}$ & $616.9^{\mathrm{L}}$ & $637.9^{\mathrm{L}}$ & & & & \\
\hline
\end{tabular}

event or that its dispersal distance is relatively short compared with those of planktonic species.

\section{The Kuroshio group}

The western coast of Kyushu is located near the route of the Tsushima Current (Fig. 1), and close genetic relationships between individuals collected in Ariake Bay and those from the Japan Sea have been demonstrated for 2 direct-developing crustaceans, the ostracod Ishizakiella miurensis (Yamaguchi 2000) and the sea louse Ligia exotica (Itani 2000). In the case of
Japanese turban shells, which are not found in Ariake Bay, the population on the western coast of Kagoshima Prefecture, the southernmost region of Kyushu, is more closely related to populations at other sites along the Tsushima Current than to those along the Kuroshio Current (Kojima et al. 2000). Unexpectedly, all 32 individuals of Batillaria cumingi from Ariake Bay belonged to the Kuroshio group (Haplotypes K1 to K5). To date, individuals of these haplotypes have been collected exclusively from Ariake Bay. Many endemic species or subspecies, of which relatives are found along the coasts of the Asian continent, have been collected in Ariake Bay (Sato 2000). They are thought to be attrib- 
Table 4. Batillaria cumingi. Genetic diversity and nucleotide composition of each population. Population numbers refer to sampling sites shown in Fig. 1

\begin{tabular}{|c|c|c|c|c|c|c|}
\hline \multirow[t]{2}{*}{ Population } & \multirow{2}{*}{$\begin{array}{c}\text { Gene } \\
\text { diversity }\end{array}$} & \multirow{2}{*}{$\begin{array}{c}\text { Nucleotide } \\
\text { diversity }\end{array}$} & \multicolumn{4}{|c|}{-Nucleotide composition (\%) } \\
\hline & & & $\mathrm{C}$ & $\mathrm{T}$ & A & $\mathrm{G}$ \\
\hline $1,2,4,5,10,21$ & $0.000 \pm 0.000$ & $0.000 \pm 0.000$ & 15.10 & 43.49 & 23.18 & 18.23 \\
\hline 3 & $0.100 \pm 0.088$ & $0.000 \pm 0.001$ & 15.10 & 43.49 & 23.19 & 18.22 \\
\hline 6,8 & $0.000 \pm 0.000$ & $0.000 \pm 0.000$ & 15.10 & 43.49 & 23.18 & 18.23 \\
\hline 7 & $0.363 \pm 0.131$ & $0.003 \pm 0.002$ & 15.17 & 43.41 & 23.18 & 18.24 \\
\hline 9,11 & $0.000 \pm 0.000$ & $0.000 \pm 0.000$ & 16.15 & 42.19 & 23.70 & 17.97 \\
\hline 12 & $0.716 \pm 0.969$ & $0.003 \pm 0.002$ & 15.94 & 42.40 & 24.05 & 17.62 \\
\hline 13 & $0.190 \pm 0.108$ & $0.001 \pm 0.001$ & 16.12 & 42.21 & 23.72 & 17.94 \\
\hline 14 & $0.268 \pm 0.113$ & $0.001 \pm 0.001$ & 15.92 & 42.41 & 23.92 & 17.75 \\
\hline 15 & $0.000 \pm 0.000$ & $0.000 \pm 0.000$ & 15.89 & 42.45 & 23.96 & 17.71 \\
\hline 16 & $0.284 \pm 0.128$ & $0.001 \pm 0.001$ & 15.86 & 42.47 & 23.97 & 17.70 \\
\hline 17 & $0.242 \pm 0.135$ & $0.001 \pm 0.001$ & 16.15 & 42.19 & 23.73 & 17.94 \\
\hline 18 & $0.100 \pm 0.088$ & $0.000 \pm 0.001$ & 16.41 & 41.93 & 23.97 & 17.70 \\
\hline 19 & $0.000 \pm 0.000$ & $0.000 \pm 0.000$ & 14.84 & 43.75 & 23.44 & 17.97 \\
\hline 20 & $0.563 \pm 0.063$ & $0.011 \pm 0.006$ & 15.68 & 42.80 & 23.53 & 17.99 \\
\hline 22 & $0.442 \pm 0.133$ & $0.002 \pm 0.002$ & 15.42 & 43.18 & 23.15 & 18.26 \\
\hline 23 & $0.716 \pm 0.088$ & $0.004 \pm 0.003$ & 15.29 & 43.29 & 23.20 & 18.22 \\
\hline 24 & $0.238 \pm 0.099$ & $0.001 \pm 0.001$ & 15.92 & 42.42 & 23.70 & 17.97 \\
\hline 25 & $0.000 \pm 0.000$ & $0.000 \pm 0.000$ & 15.36 & 43.23 & 23.18 & 18.23 \\
\hline 26 & $0.482 \pm 0.113$ & $0.001 \pm 0.001$ & 15.31 & 43.28 & 23.15 & 18.26 \\
\hline Total & $0.849 \pm 0.009$ & $0.012 \pm 0.007$ & 15.54 & 42.95 & 23.47 & 18.05 \\
\hline
\end{tabular}

utable to connections between the western coast of Kyushu and coastal areas of the Asian continent during glacial periods. After the last glacial period, most species found in Ariake Bay were isolated from conspecific populations on the continental coast and are likely to have diverged, in some cases, at the subspecies or species level. As all individuals of $B$. cumingi collected on the Korean Peninsula were classified into the Tsushima group, the divergence of the population in Ariake Bay from those on the Asian continent might have occurred before the last glacial period.

Two dominant haplotypes, K6 and K13, and rare haplotypes that were thought to have derived from these 2 dominant haplotypes, K7 to 12 and K14 to 16 (Fig. 3), inhabit the Pacific coast of Honshu. The nested cladogram of haplotypes (Fig. 3) suggests that the dominant haplotypes K6 and K13 were derived independently from K1, the dominant haplotype in Ariake Bay, as the monophyly of haplotypes of the Kuroshio group was supported by a high bootstrap probability (Fig. 2) and the root of the cladogram is thought to be outside the clade of the Kuroshio group. As shown by the high endemicity of marine fauna, Ariake Bay is a semi-closed area, connected to the outside by relatively narrow straits, and populations of marine organisms in Ariake Bay are thought to have been isolated with the extension of the bay after the glacial periods (Shimoyama et al. 1996, Sato 2000, Sato 2001). Individuals of haplotypes of Clades 1-2 and 1-3 in Fig. 3 might have been derived from populations isolated from the population in Ariake Bay during different ages. The temporal influx of the Oyashio Current into the Japan Sea through the Tsugaru Strait at the end of the glacial periods might have prevented Batillaria cumingi from colonizing the Japan Sea coast. The nested clade analysis suggests past fragmentation within Clade 2-1 (Table 3), which supports this hypothesis. In addition, the mismatch distribution indicates that individuals of the Kuroshio group experienced a sudden expansion (Fig. 4a).

At present, the Kuroshio Current and the Oyashio Current converge off the northern coast of the Kanto district, near Site 11 in Fig. 1, while a boundary between the Tsushima group and the Kuroshio group is apparent near Site 7 on the NE coast of Honshu (Fig. 1). Approximately $6000 \mathrm{yr}$ ago, the front of the Kuroshio Current appears to have reached a region off the NE coast of Honshu, and this region is the northernmost position achieved by the Current during the past 20000 yr (Chinzei et al. 1987, Oda \& Takemoto 1992). Individuals of the Kuroshio group that inhabit the NE coast of Honshu are thought to have been transported by the Kuroshio Current at that time.

\section{The Tsushima group}

The Japan Sea is very interesting for phylogeographic studies (Kojima et al. 1997, 2000, 2001b, Itani 2000, Yamaguchi 2000). This semi-enclosed sea is connected with neighboring seas by relatively shallow and narrow straits. During glacial periods, it is probable 
Table 5. Batillaria cumingi. (Above diagonal) Pairwise $F_{\mathrm{ST}}$ values between populations and (below diagonal) the exact test of population differentiation. ${ }^{*}$ Significant differentiation at the $5 \%$ level. ${ }^{* *}$ Significant differentiation at the $1 \%$ level. nd $=$ not determined, the exact test was not possible because all samples of 2 populations had an identical haplotype. Sampling sites refer to numbers in Fig. 1

\begin{tabular}{|c|c|c|c|c|c|c|c|c|c|c|c|c|c|}
\hline & 1 & 2 & 3 & 4 & 5 & 6 & 7 & 8 & 9 & 10 & 11 & 12 & 13 \\
\hline 1 & & 0.00 & 0.00 & 0.00 & 0.00 & $1.00^{* *}$ & 0.09 & $1.00^{* *}$ & $1.00^{* *}$ & 0.00 & $1.00^{* *}$ & $0.64^{* *}$ & $0.91^{* *}$ \\
\hline 2 & nd & & -0.07 & 0.00 & 0.00 & $1.00^{* *}$ & 0.00 & $1.00^{* *}$ & $1.00^{* *}$ & 0.00 & $1.00^{* *}$ & $0.53^{* *}$ & $0.86^{* *}$ \\
\hline 3 & 1.00 & 1.00 & & 0.00 & $0.00^{* *}$ & $0.95^{* *}$ & 0.04 & $0.95^{* *}$ & $0.95^{* *}$ & $0.00^{* *}$ & $0.95^{* *}$ & $0.59^{* *}$ & $0.86^{* *}$ \\
\hline 4 & nd & nd & 1.00 & & 0.00 & $1.00^{* *}$ & 0.09 & $1.00^{* *}$ & $1.00^{* *}$ & 0.00 & $1.00^{* *}$ & $0.64^{* *}$ & $0.91^{* *}$ \\
\hline 5 & nd & nd & 0.48 & nd & & $1.00^{* *}$ & $0.10^{* *}$ & $1.00^{* *}$ & $1.00^{* *}$ & 0.00 & $1.00^{* *}$ & $0.65^{* *}$ & $0.91^{* *}$ \\
\hline 6 & $0.00^{* *}$ & $0.00^{* *}$ & $0.00^{* *}$ & $0.00^{* *}$ & $0.00^{* *}$ & & $0.81^{* *}$ & 0.00 & $1.00^{* *}$ & $1.00^{* *}$ & $1.00^{* *}$ & $0.64^{* *}$ & $0.91^{* *}$ \\
\hline 7 & 0.11 & 1.00 & 0.22 & 0.10 & $0.05^{*}$ & $0.00^{* *}$ & & $0.82^{* *}$ & $0.81^{* *}$ & $0.10^{* *}$ & $0.81^{* *}$ & $0.46^{* *}$ & $0.71^{* *}$ \\
\hline 8 & $0.00^{* *}$ & $0.00^{* *}$ & $0.00^{* *}$ & $0.00^{* *}$ & $0.00^{* *}$ & nd & $0.00^{* *}$ & & $1.00^{* *}$ & $1.00^{* *}$ & $1.00^{* *}$ & $0.64^{* *}$ & $0.91^{* *}$ \\
\hline 9 & $0.00^{* *}$ & $0.00^{* *}$ & $0.00^{* *}$ & $0.00^{* *}$ & $0.00^{* *}$ & $0.00^{* *}$ & $0.00^{* *}$ & $0.00^{* *}$ & & $1.00^{* *}$ & 0.00 & $0.62^{* *}$ & 0.05 \\
\hline 10 & nd & nd & 0.48 & nd & nd & $0.00^{* *}$ & $0.04^{*}$ & $0.00^{* *}$ & $0.00^{* *}$ & & $1.00^{* *}$ & $0.65^{* *}$ & $0.91^{* *}$ \\
\hline 11 & $0.00^{* *}$ & $0.00^{* *}$ & $0.00^{* *}$ & $0.00^{* *}$ & $0.00^{* *}$ & $0.00^{* *}$ & $0.00^{* *}$ & $0.00^{* *}$ & nd & $0.00^{* *}$ & & $0.62^{* *}$ & 0.05 \\
\hline 12 & $0.00^{* *}$ & $0.00^{* *}$ & $0.00^{* *}$ & $0.00^{* *}$ & $0.00^{* *}$ & $0.00^{* *}$ & $0.00^{* *}$ & $0.00^{* *}$ & $0.00^{* *}$ & $0.00^{* *}$ & $0.00^{* *}$ & & $0.51^{* *}$ \\
\hline 13 & $0.00^{* *}$ & $0.00^{* *}$ & $0.00^{* *}$ & $0.00^{* *}$ & $0.00^{* *}$ & $0.00^{* *}$ & $0.00^{* *}$ & $0.00^{* *}$ & 0.48 & $0.00^{* *}$ & 0.48 & $0.00^{* *}$ & \\
\hline 14 & $0.00^{* *}$ & $0.00^{* *}$ & $0.00^{* *}$ & $0.00^{* *}$ & $0.00^{* *}$ & $0.00^{* *}$ & $0.00^{* *}$ & $0.00^{* *}$ & $0.00^{* *}$ & $0.00^{* *}$ & $0.00^{* *}$ & $0.00^{* *}$ & $0.00^{* *}$ \\
\hline 15 & $0.00^{* *}$ & $0.00^{* *}$ & $0.00^{* *}$ & $0.00^{* *}$ & $0.00^{* *}$ & $0.00^{* *}$ & $0.00^{* *}$ & $0.00^{* *}$ & $0.00^{* *}$ & $0.00^{* *}$ & $0.00^{* *}$ & $0.00^{* *}$ & $0.00^{* *}$ \\
\hline 16 & $0.00^{* *}$ & $0.00^{* *}$ & $0.00^{* *}$ & $0.00^{* *}$ & $0.00^{* *}$ & $0.00^{* *}$ & $0.00^{* *}$ & $0.00^{* *}$ & $0.00^{* *}$ & $0.00^{* *}$ & $0.00^{* *}$ & $0.00^{* *}$ & $0.00^{* *}$ \\
\hline 17 & $0.00^{* *}$ & $0.00^{* *}$ & $0.00^{* *}$ & $0.00^{* *}$ & $0.00^{* *}$ & $0.00^{* *}$ & $0.00^{* *}$ & $0.00^{* *}$ & 0.19 & $0.00^{* *}$ & 0.20 & $0.00^{* *}$ & 0.25 \\
\hline 18 & $0.00^{* *}$ & $0.00^{* *}$ & $0.00^{* *}$ & $0.00^{* *}$ & $0.00^{* *}$ & $0.00^{* *}$ & $0.00^{* *}$ & $0.00^{* *}$ & $0.00^{* *}$ & $0.00^{* *}$ & $0.00^{* *}$ & $0.00^{* *}$ & $0.00^{* *}$ \\
\hline 19 & $0.00^{* *}$ & $0.00^{* *}$ & $0.00^{* *}$ & $0.00^{* *}$ & $0.00^{* *}$ & $0.00^{* *}$ & $0.00^{* *}$ & $0.00^{* *}$ & $0.00^{* *}$ & $0.00^{* *}$ & $0.00^{* *}$ & $0.00^{* *}$ & $0.00^{* *}$ \\
\hline 20 & $0.00^{* *}$ & $0.00^{* *}$ & $0.00^{* *}$ & $0.00^{* *}$ & $0.00^{* *}$ & $0.00^{* *}$ & $0.00^{* *}$ & $0.00^{* *}$ & $0.00^{* *}$ & $0.00^{* *}$ & $0.00^{* *}$ & $0.00^{* *}$ & $0.00^{* *}$ \\
\hline 21 & nd & nd & 1.00 & nd & nd & $0.00^{* *}$ & 0.11 & $0.00^{* *}$ & $0.00^{* *}$ & nd & $0.00^{* *}$ & $0.00^{* *}$ & $0.00^{* *}$ \\
\hline 22 & $0.00^{* *}$ & $0.00^{* *}$ & $0.00^{* *}$ & $0.00^{* *}$ & $0.00^{* *}$ & $0.00^{* *}$ & $0.00^{* *}$ & $0.00^{* *}$ & $0.00^{* *}$ & $0.00^{* *}$ & $0.00^{* *}$ & $0.00^{* *}$ & $0.00^{* *}$ \\
\hline 23 & $0.00^{* *}$ & $0.00^{* *}$ & $0.00^{* *}$ & $0.00^{* *}$ & $0.00^{* *}$ & $0.00^{* *}$ & $0.00^{* *}$ & $0.00^{* *}$ & $0.00^{* *}$ & $0.00^{* *}$ & $0.00^{* *}$ & $0.00^{* *}$ & $0.00^{* *}$ \\
\hline 24 & $0.00^{* *}$ & $0.00^{* *}$ & $0.00^{* *}$ & $0.00^{* *}$ & $0.00^{* *}$ & $0.00^{* *}$ & $0.00^{* *}$ & $0.00^{* *}$ & $0.00^{* *}$ & $0.00^{* *}$ & $0.00^{* *}$ & $0.00^{* *}$ & $0.00^{* *}$ \\
\hline 25 & $0.00^{* *}$ & $0.00^{* *}$ & $0.00^{* *}$ & $0.00^{* *}$ & $0.00^{* *}$ & $0.00^{* *}$ & $0.00^{* *}$ & $0.00^{* *}$ & $0.00^{* *}$ & $0.00^{* *}$ & $0.00^{* *}$ & $0.00^{* *}$ & $0.00^{* *}$ \\
\hline \multirow[t]{2}{*}{26} & $0.00^{* *}$ & $0.00^{* *}$ & $0.00^{* *}$ & $0.00^{* *}$ & $0.00^{* *}$ & $0.00^{* *}$ & $0.00^{* *}$ & $0.00^{* *}$ & $0.00^{* *}$ & $0.00^{* *}$ & $0.00^{* *}$ & $0.00^{* *}$ & $0.00^{* *}$ \\
\hline & 14 & 15 & 16 & 17 & 18 & 19 & 20 & 21 & 22 & 23 & 24 & 25 & 26 \\
\hline 1 & $0.87^{* *}$ & $1.00^{* *}$ & $0.86^{* *}$ & $0.89^{* *}$ & $0.95^{* *}$ & $1.00^{* *}$ & $0.72^{* *}$ & 0.00 & $0.78^{* *}$ & $0.64^{* *}$ & $6^{* *}$ & )** & $0.70^{* *}$ \\
\hline 2 & $0.81^{* *}$ & $1.00^{* *}$ & $0.80^{* *}$ & $0.83^{* *}$ & $0.93^{* *}$ & $1.00^{* *}$ & $0.62^{* *}$ & 0.00 & $0.69^{* *}$ & $0.53^{* *}$ & $0.81^{* *}$ & $1.00^{* *}$ & $0.59^{* *}$ \\
\hline 3 & $0.82^{* *}$ & $0.95^{* *}$ & $0.81^{* *}$ & $0.84^{* *}$ & $0.90^{* *}$ & $0.95^{* *}$ & $0.66^{* *}$ & 0.00 & $0.73^{* *}$ & $0.59^{* *}$ & $0.82^{* *}$ & $0.93^{* *}$ & $0.64^{* *}$ \\
\hline 4 & $0.87^{* *}$ & $1.00^{* *}$ & $0.86^{* *}$ & $0.89^{* *}$ & $0.95^{* *}$ & $1.00^{* *}$ & $0.72^{* *}$ & 0.00 & $0.78^{* *}$ & $0.64^{* *}$ & $0.86^{* *}$ & $1.00^{* *}$ & $0.70^{* *}$ \\
\hline 5 & $0.87^{* *}$ & $1.00^{* *}$ & $0.86^{* *}$ & $0.89^{* *}$ & $0.95^{* *}$ & $1.00^{* *}$ & $0.72^{* *}$ & 0.00 & $0.78^{* *}$ & $0.65^{* *}$ & $0.86^{* *}$ & $1.00^{* *}$ & $0.70^{* *}$ \\
\hline 6 & $0.87^{* *}$ & $1.00^{* *}$ & $0.86^{* *}$ & $0.89^{* *}$ & $0.95^{* *}$ & $1.00^{* *}$ & $0.37^{* *}$ & $1.00^{* *}$ & $0.78^{* *}$ & $0.55^{* *}$ & $0.86^{* *}$ & $1.00^{* *}$ & $0.76^{* *}$ \\
\hline 7 & $0.68^{* *}$ & $0.82^{* *}$ & $0.68^{* *}$ & $0.68^{* *}$ & 0.7 & $0.82^{* *}$ & $0.54^{* *}$ & 0.09 & $0.60^{* *}$ & $0.46^{* *}$ & 0.7 & $0.76^{* *}$ & $0.50^{* *}$ \\
\hline 8 & $0.87^{* *}$ & $1.00^{* *}$ & $0.86^{* *}$ & $0.89^{* *}$ & $0.95^{* *}$ & $1.00^{* *}$ & $0.37^{* *}$ & $1.00^{* *}$ & $0.78^{* *}$ & $0.55^{* *}$ & $0.86^{* *}$ & $1.00^{* *}$ & $0.76^{* *}$ \\
\hline 9 & $0.84^{* *}$ & $1.00^{* *}$ & $0.86^{* *}$ & 0.05 & $0.95^{* *}$ & $1.00^{* *}$ & $0.72^{* *}$ & $1.00^{* *}$ & $0.78^{* *}$ & $0.64^{* *}$ & $0.86^{* *}$ & $1.00^{* *}$ & $0.76^{* *}$ \\
\hline 10 & $0.87^{* *}$ & $1.00^{* *}$ & $0.86^{* *}$ & $0.90^{* *}$ & $0.95^{* *}$ & $1.00^{* *}$ & $0.73^{* *}$ & 0.00 & $0.79^{* *}$ & $0.65^{* *}$ & $0.86^{* *}$ & $1.00^{* *}$ & $0.71^{* *}$ \\
\hline 11 & $0.84^{* *}$ & $1.00^{* *}$ & $0.86^{* *}$ & 0.05 & $0.95^{* *}$ & $1.00^{* *}$ & $0.72^{* *}$ & $1.00^{* *}$ & $0.78^{* *}$ & $0.64^{* *}$ & $0.86^{* *}$ & $1.00^{* *}$ & $0.76^{* *}$ \\
\hline 12 & $0.33^{* *}$ & $0.49^{* *}$ & $0.33^{* *}$ & $0.48^{* *}$ & $0.59^{* *}$ & $0.64^{* *}$ & $0.36^{* *}$ & $0.64^{* *}$ & $0.42^{* *}$ & $0.28^{* *}$ & $0.56^{* *}$ & $0.55^{* *}$ & $0.40^{* *}$ \\
\hline 13 & $0.71^{* *}$ & $0.89^{* *}$ & $0.74^{* *}$ & -0.01 & $0.86^{* *}$ & $0.91^{* *}$ & $0.62^{* *}$ & $0.91^{* *}$ & $0.68^{* *}$ & $0.55^{* *}$ & $0.78^{* *}$ & $0.87^{* *}$ & $0.66^{* *}$ \\
\hline 14 & & 0.11 & 0.00 & $0.71^{* *}$ & $0.82^{* *}$ & $0.87^{* *}$ & $0.58^{* *}$ & $0.87^{* *}$ & $0.64^{* *}$ & $0.51^{* *}$ & $0.75^{* *}$ & $0.82^{* *}$ & $0.62^{* *}$ \\
\hline 15 & 0.22 & & 0.05 & $0.89^{* *}$ & $0.95^{* *}$ & $1.00^{* *}$ & $0.72^{* *}$ & $1.00^{* *}$ & $0.78^{* *}$ & $0.64^{* *}$ & $0.86^{* *}$ & $1.00^{* *}$ & $0.76^{* *}$ \\
\hline 16 & 0.25 & 0.24 & & $0.74^{* *}$ & $0.81^{* *}$ & $0.86^{* *}$ & $0.58^{* *}$ & $0.86^{* *}$ & $0.64^{* *}$ & $0.50^{* *}$ & $0.74^{* *}$ & $0.81^{* *}$ & $0.62^{* *}$ \\
\hline 17 & $0.00^{* *}$ & $0.00^{* *}$ & $0.00^{* *}$ & & $0.83^{* *}$ & $0.89^{* *}$ & $0.59^{* *}$ & $0.89^{* *}$ & $0.65^{* *}$ & $0.51^{* *}$ & $0.76^{* *}$ & $0.85^{* *}$ & $0.63^{* *}$ \\
\hline 18 & $0.00^{* *}$ & $0.00^{* *}$ & $0.00^{* *}$ & $0.00^{* *}$ & & $0.95^{* *}$ & $0.47^{* *}$ & $0.95^{* *}$ & $0.73^{* *}$ & $0.59^{* *}$ & $0.82^{* *}$ & $0.93^{* *}$ & $0.71^{* *}$ \\
\hline 19 & $0.00^{* *}$ & $0.00^{* *}$ & $0.00^{* *}$ & $0.00^{* *}$ & $0.00^{* *}$ & & $0.72^{* *}$ & $1.00^{* *}$ & $0.78^{* *}$ & $0.64^{* *}$ & $0.86^{* *}$ & $1.00^{* *}$ & $0.76^{* *}$ \\
\hline 20 & $0.00^{* *}$ & $0.00^{* *}$ & $0.00^{* *}$ & $0.00^{* *}$ & $0.00^{* *}$ & $0.00^{* *}$ & & $0.72^{* *}$ & $0.50^{* *}$ & $0.28^{* *}$ & $0.63^{* *}$ & $0.64^{* *}$ & $0.48^{* *}$ \\
\hline 21 & $0.00^{* *}$ & $0.00^{* *}$ & $0.00^{* *}$ & $0.00^{* *}$ & $0.00^{* *}$ & $0.00^{* *}$ & $0.00^{* *}$ & & $0.78^{* *}$ & $0.64^{* *}$ & $0.86^{* *}$ & $1.00^{* *}$ & $0.70^{* *}$ \\
\hline 22 & $0.00^{* *}$ & $0.00^{* *}$ & $0.00^{* *}$ & $0.00^{* *}$ & $0.00^{* *}$ & $0.00^{* *}$ & $0.00^{* *}$ & $0.00^{* *}$ & & $0.06^{* *}$ & $0.68^{* *}$ & 0.05 & 0.02 \\
\hline 23 & $0.00^{* *}$ & $0.00^{* *}$ & $0.00^{* *}$ & $0.00^{* *}$ & $0.00^{* *}$ & $0.00^{* *}$ & $0.00^{* *}$ & $0.00^{* *}$ & $0.04^{*}$ & & $0.56^{* *}$ & 0.19 & $0.08^{*}$ \\
\hline 24 & $0.00^{* *}$ & $0.00^{* *}$ & $0.00^{* *}$ & $0.00^{* *}$ & $0.00^{* *}$ & $0.00^{* *}$ & $0.00^{* *}$ & $0.00^{* *}$ & $0.00^{* *}$ & $0.00^{* *}$ & & $0.82^{* *}$ & $0.66^{* *}$ \\
\hline 25 & $0.00^{* *}$ & $0.00^{* *}$ & $0.00^{* *}$ & $0.00^{* *}$ & $0.00^{* *}$ & $0.00^{* *}$ & $0.00^{* *}$ & $0.00^{* *}$ & 0.86 & 0.29 & $0.00^{* *}$ & & 0.11 \\
\hline 26 & $0.00^{* *}$ & $0.00^{* *}$ & $0.00^{* *}$ & $0.00^{* *}$ & $0.00^{* *}$ & $0.00^{* *}$ & $0.00^{* *}$ & $0.00^{* *}$ & $0.03^{*}$ & $0.00^{* *}$ & $0.00^{* *}$ & 0.25 & \\
\hline
\end{tabular}


Table 6. Batillaria cumingi. Analysis of Molecular Variance (AMOVA) for genetic structure among stations. $\mathrm{p}=$ probability of having a more extreme variance component and $\phi$-statistic than values observed by chance alone (1000 permutations)

\begin{tabular}{|lcccc|}
\hline & Variance & $\%$ of variance & $\phi$-statistic & $\mathrm{p}$ \\
\hline Among groups & 0.115 & 23.24 & 0.232 & $<0.001$ \\
Among populations within groups & 0.285 & 57.56 & 0.808 & $<0.001$ \\
Within populations & 0.095 & 19.20 & 0.750 & $<0.001$ \\
\hline
\end{tabular}

persal through the Kanmon Strait during the past $5000 \mathrm{yr}$. In addition to dispersal from the Japan Sea to the Seto Inland Sea, dispersal from the Seto Inland Sea to the Japan Sea has also been clearly demonstrated for Japanese turban shells (Kojima et al. 1997). In contrast, no such dispersal was detected in the case of Batillaria cumingi. Such a difference in distribution might also be attributable to the

that it was almost completely isolated. In addition, it has been proposed that a massive influx of freshwater from the Asian continent during the last glacial maximum (27000 to 20000 yr ago) prevented vertical circulation and caused severely anoxic conditions (Tada 1994, Crusius et al. 1999, Ishikawa et al. 1999, Tada et al. 1999). In addition, the decrease in water temperature due to the interruption of the Tsushima Current should have made most habitats of the Tsushima group uncomfortable. The low genetic diversity of populations on the coasts of the Japan Sea, the Sanriku district, and Hokkaido (Table 2) might be attributable to the severe bottleneck of populations during the glacial period. After the glacial period, the population of the Tsushima group probably experienced a sudden expansion, as suggested by the results of the mismatch distribution analysis (Fig. 4b).

Based on micropaleontologic analyses of core sediment samples, Gorbarenko \& Southon (2000) showed that the sea area on the eastern slope of the Tsushima Strait did not become anoxic during the last glacial period, and they attributed this phenomenon to a small but constant influx of fresh seawater through the Tsushima Strait. The phylogeographic structure of the deep-sea demersal fish Bothrocara hollandi in the Japan Sea supports their conclusion, and it has been suggested that this fish used the area as a refuge during the last glacial period (Kojima et al. 2001b). Available habitats for intertidal gastropods might not have been as severely limited as they were for deep-sea demersal fish, even during the last glacial maximum. Populations in the Hokuriku district (Sites 6 and 8 in Fig. 1) and Shimane Prefecture (Site 19 in Fig. 1) might have originated from other isolated refuges in the Japan Sea, where a single haplotype was randomly fixed through reductions in population size during the last glacial period. The past fragmentation suggested by the nested clade analysis for Clade 2-4 (Table 3) supports this hypothesis.

The Seto Inland Sea is connected to the Japan Sea by the Kanmon Strait, which was formed about 5000 yr ago (Ohshima 1990). Individuals in the Tsushima group that inhabit the western part of the Seto Inland Sea (Site 20 in Fig. 1) are probably the result of dis- lower dispersal ability of $B$. cumingi in comparison with Japanese turban shells.

Analysis of the genetic structures of marine organisms not only provides information about historical variations in oceanic environments but also provides fundamental data for estimations of the effects of future environmental changes on marine ecosystems. In addition, such data are also important in terms of conservation biology. Many species inhabiting tidelands in Japan have been severely affected by reclamation and/or pollution during the recent explosive development of coastal areas (Wada et al. 1996). Thus, detailed knowledge of the genetic status of each species is indispensable for the conservation of populations in the remaining habitats. The use of fasterevolving molecules than COI might give a more contemporary view of the genetic structure. To clarify the organization of fauna in Japanese coastal areas, we must obtain genetic information on species in neighboring regions, such as the coasts of Russia, the Korean Peninsula, continental China, and Taiwan, and examine related species with various types of larvae and geographic distributions.

Acknowledgements. The authors thank N. Abe, H. Fukuda, M. Hamaguchi, Y. Hashiguchi, Y. Hirano, H. Ito, T. Kimura, K. Kinoshita, T. Koga, K. Mori, N. Nakabayashi, M. Nakaoka, E. Nishi, R. Ogasaka, N. Ota, T. Uchino, and H. Yamashita for their help in the collection of samples. Part of this study was supported by grants to S.K. from the Ministry of Education, Sports, Culture, Science and Technology of Japan (Nos. 10836007, 13640693, and 12NP0201).

\section{LITERATURE CITED}

Adachi N, Wada K (1999) Distribution in relation to life history in the direct-developing gastropod Batillaria cumingi (Batillariidae) on two shores of contrasting substrata. J Moll Stud 65:275-287

Avise JC (1992) Molecular population structure and the biogeographic history of regional fauna: a case study with lessons for conservation biology. Oikos 63:62-76

Avise JC (1994) Molecular markers, natural history and evolution. Chapman \& Hall, New York

Avise JC (2000) Phylogeography, the history and formation of species. Harvard University Press, Cambridge, MA 
Borsa P, Naciri M, Bahri L, Chikhi L, Garcia de Leon FJ, Kotoulas G, Bonhomme F (1997) Infraspecific zoogeography of the Mediterranean: population genetic analysis on sixteen atlanto-mediterranean species (fishes and invertebrates). Vie Milieu 47:295-305 (in French with English abstract)

Chinzei K (1978) Neogene molluscan faunas in the Japanese Islands: an ecologic and zoogeographic synthesis. Veliger 21:155-170

Chinzei K, Fujioka K, Kitazato H, Koizumi I and 5 others (1987) Postglacial environmental change of the Pacific Ocean off the coasts of Central Japan. Mar Micropaleontol 11:273-291

Clement M, Posada D, Crandall KA (2000) TCS: a computer program to estimate gene genealogies. Mol Ecol 9: $1657-1660$

Collin R (2001) The effects of mode of development on phylogeography and population structure of North Atlantic Crepidula (Gastropoda: Calyptraeidae). Mol Ecol 10: 2249-2262

Crusius J, Pedersen TF, Calvert SE, Cowie GL, Oba T (1999) A 36 kyr geographical record from the Sea of Japan of organic matter flux variations and changes in intermediate water oxygen concentration. Paleoceanography 14 : 248-259

Excoffier L, Smouse PE, Quattro JM (1992) Analysis of molecular variance inferred from metric distances among DNA haplotypes: application to human mitochondrial DNA restriction data. Genetics 131:479-491

Furota T, Sonobe T, Arita S (2002) Contrasting population status between the planktonic and direct development batillariid snails Batillaria multiformis (Lischke) and B. cumingi (Crosse) on an isolated tidal flat in Tokyo Bay. Venus 61: $15-23$

Gorbarenko SA, Southon JR (2000) Detailed Japan Sea paleoceanography during the last 25 kyr: constraints from AMS dating and $\delta^{18} \mathrm{O}$ of planktonic foraminifera. Palaeogeogr Palaeoclimatol Palaeoecol 126:177-193

Hasegawa K (2000) Batillariidae. In: Okutani T (ed) Marine mollusks in Japan. Tokai University Press, Tokyo, p 130-133

Hellberg ME, Vacquier VD (1999) Rapid evolution of fertilization selectivity and lysin cDNA sequences in Teguline gastropods. Mol Biol Evol 16:839-848

Hellberg ME, Balch DP, Roy K (2001) Climate-driven range expansion and morphological evolution in a marine gastropod. Science 292:1707-1710

Helmuth B, Veit RR, Holberton R (1994) Long-distance dispersal of a subantarctic brooding bivalve (Gaimardia trapesina) by kelp-rafting. Mar Biol 120:421-426

Highsmith RC (1985) Floating and algal rafting as potential dispersal mechanisms in brooding invertebrates. Mar Ecol Prog Ser 25:169-179

Hoffman RJ, Boore JL, Brown WM (1992) A novel mitochondrial genome organization for the blue mussel, Mytilus edulis. Genetics 131:397-412

Hoskin MG (1997) Effects of contrasting modes of larval development on the genetic structures of populations of three species of prosobranch gastropods. Mar Biol 127: $647-656$

Ishikawa R, Yamada K, Matsumoto K, Houtatsu M, Naraoka $H$ (1999) Organic molecular and carbon isotopic records of the Japan Sea over the past 30 kyr. Paleoceanography 14: $260-270$

Itani Y (2000) Phylogeography of Japanese Ligia species (Isopoda: Crustacea) based on molecular phylogenetic analysis. Monthly Kaiyo 32:246-251 (in Japanese)
Johannesson K, Johannesson B (1995) Dispersal and population expansion in a direct developing marine snail (Littorina saxatilis) following a severe population bottleneck. Hydrobiologia 309:173-180

Kojima S, Segawa R, Hayashi I (1997) Genetic differentiation among populations of the Japanese turban shell Turbo (Batillus) cornutus corresponding to warm current. Mar Ecol Prog Ser 150:149-155

Kojima S, Segawa R, Hayashi I (2000) Stability of the courses of the warm coastal currents along the Kyushu Island suggested by the population structure of the Japanese turban shell Turbo (Batillus) cornutus. J Oceanogr 56:601-604

Kojima S, Ota N, Mori K, Kurozumi T, Furota T (2001a) Molecular phylogeny of Japanese gastropods in the genus Batillaria. J Moll Stud 67:381-388

Kojima S, Segawa R, Hayashi I, Okiyama M (2001b) Phylogeography of a deep-sea demersal fish, Bothrocara hollandi, in the Japan Sea. Mar Ecol Prog Ser 217:135-143

Kojima S, Kamimura S, Kimura T, Hayashi I, Iijima A, Furota $T$ (2003) Phylogenetic relationships between the tideland snails Batillaria flectosiphonata in the Ryukyu Islands and B. multiformis in the Japanese Islands. Zool Sci 20: 1423-1433

Kurozumi T (1995) Batillaria multiformis. In: Japan Fisheries Resources Conservation Association (ed) Fundamental data on rare aquatic organisms in Japan, Part 2. Japan Fisheries Resources Conservation Association, Tokyo, p 73-78 (in Japanese)

Kyle CJ, Boulding EG (2000) Comparative population structure of marine gastropods (Littorina spp.) with and without pelagic larval dispersal. Mar Biol 137:835-845

Malone CR (1965) Killdeer (Charadrius vociferus Linnaeus) as a means of dispersal for aquatic gastropods. Ecology 46: $551-552$

Martel A, Chia FS (1991) Drifting and dispersal of small bivalves and gastropods with direct development. J Exp Mar Biol Ecol 150:131-147

Nei M (1987) Molecular evolutionary genetics. Columbia University Press, New York

Oda M, Takemoto A (1992) Planktonic foraminifera and paleoceanography in the domain of the Kuroshio Current around Japan during the last 20,000 years. Quat Res Tokyo 31:341-357 (in Japanese with English abstract)

Ohshima K (1990) The history of straits around Japanese Islands in the Late-Quaternary. Quat Res Tokyo 29: 193-208 (in Japanese with English abstract)

Posada D, Crandall KA, Templeton AR (2000) GeoDis: a program for the cladistic nested analysis of the geographical distribution of genetic haplotypes. Mol Ecol 9:487-488

Raymond M, Rousset F (1995) An exact test for population differentiation. Evolution 49:1280-1283

Rogers AR (1995) Genetic evidence for a Pleistocene population expansion. Evolution 49:608-615

Sato M (ed) (2000) Life in the Ariake Sea: biodiversity in tidal flats and estuaries. Kaiyusya, Tokyo (in Japanese)

Sato S (2001) Temporal changes of bivalves and gastropods in Isahaya Bay shut off from Ariake Sea, western Kyushu, Japan. Quat Res Tokyo 40:85-95 (in Japanese with English abstract)

Sawada K, Handa N (1998) Variability of the path of the Kuroshio ocean current over the last 25,000 years. Nature 392:592-595

Schneider S, Roessli D, Excoffier L (2000) Arlequin: a software for population genetic data analysis, Ver 2.000. Genetics and Biometry Laboratory, Department of Anthropology, University of Geneva, Geneva

Shimoyama S, Kosugi M, Matsuoka K, Kataoka H and 7 oth- 
ers (1996) Integral analysis for the paleoenvironment of the coastal lowland around the innermost Ariake Bay, West Japan. Kanto Heiya 4:53-76 (in Japanese)

Shimayama T, Himeno H, Sasuga J, Yokobori S, Ueda T, Watanabe K (1990) The genetic code of a squid mitochondrial gene. Nucleic Acids Symp Ser 22:77-78

Swofford DL (2002) PAUP*. Phylogenetic analysis using parsimony (*and other methods), Version 4.0b10. Sinauer Associates, Sunderland, MA

Tada R (1994) Paleoceanographic evolution of the Japan Sea. Palaeogeogr Palaeoclimatol Palaeoecol 108:487-508

Tada R, Irino T, Koizumi I (1999) Land-ocean linkages over orbital and millennial timescales recorded in late Quaternary sediments of the Japan Sea. Paleoceanography 14: 236-247

Tajima F (1983) Evolutionary relationship of DNA sequences in finite populations. Genetics 105:437-460

Tajima F (1989) Statistical method for testing the neutral mutation hypothesis by DNA polymorphism. Genetics 123:585-595

Templeton AR, Sing CF (1993) A cladistic analysis of phenotypic associations with haplotypes inferred from restriction endonuclease mapping. IV. Nested analyses with cladogram uncertainty and recombination. Genetics 134: 659-669

Templeton AR, Boerwinkle E, Sing CF (1987) A cladistic analysis of phenotypic associations with haplotypes inferred from restriction endonuclease mapping. I. Basic theory and an analysis of alcohol dehydrogenase activity in Drosophila. Genetics 117:343-351

Templeton AR, Routman E, Phillips CA (1995) Separating population structure from population history: a cladistic analysis of the geographical distribution of mitochondrial DNA haplotypes in the tiger salamander, Ambystoma tigrinum. Genetics 140:769-782

Editorial responsibility: Otto Kinne (Editor),

Oldendorf/Luhe, Germany
Todd CD, Lambert WJ, Thorpe JP (1998) The genetic structure of intertidal populations of two species of nudibranch mollusks with planktonic and pelagic lecithotrophic larval stages: are pelagic larvae 'for' dispersal? J Exp Mar Biol Ecol 228:1-28

Unoki S, Kubota M (1996) Waves and currents in the ocean. Tokai University Press, Tokyo (in Japanese)

Wada K, Nishihira M, Furota T, Nojima S and 7 others (1996) Present status of estuarine locales and benthic invertebrates occurring in estuarine environment in Japan. WWF Jpn Sci Rep 3:1-182 (in Japanese with English abstract)

Wares JP (2002) Community genetics in the northwestern Atlantic intertidal. Mol Ecol 11:1131-1144

Wares JP, Cunningham CW (2001) Phylogeography and historical ecology of the North Atlantic intertidal. Evolution 55:2455-2469

Wares JP, Gaines SD, Cunningham C (2001) A comparative study of asymmetric migration events across a marine biogeographic boundary. Evolution 55:295-306

Weir BS, Cockerham CC (1984) Estimation of F-statistics for the analysis of population structure. Evolution 38:1358-1370

Wilke T, Davis GM (2000) Intraspecific mitochondrial sequence diversity in Hydrobia ulvae and Hydrobia ventrosa (Hydrobiidae: Rissooidea: Gastropoda): do their different life histories affect biogeographic patterns and gene flow? Biol J Linn Soc 70:89-105

Yamaguchi S (2000) Phylogenetic and biogeographical history of the genus Ishizakiella (Ostracoda) inferred from mitochondrial COI gene sequences. J Crust Biol 20: 357-384

Zane L, Ostellari L, Maccatrozzo L, Bargelloni L, CuzinRoudy J, Buchholz F, Patarnello T (2000) Genetic differentiation in a pelagic crustacean (Meganyctiphanes norvegica: Euphausiacea) from the North East Atlantic and the Mediterranean Sea. Mar Biol 136:191-199

Submitted: June 18, 2002; Accepted: March 9, 2004

Proofs received from author(s): July 19, 2004 